\title{
Further evidence of Ceratobasidium D.P. Rogers (Basidiomycota) serving as the ubiquitous fungal associate of Platanthera leucophaea (Orchidaceae) in the North American tallgrass prairie
}

\author{
Hana L. Thixton ${ }^{1,2,3}$, Elizabeth J. Esselman ${ }^{1}$, Laura L. Corey ${ }^{2}$ and Lawrence W. Zettler ${ }^{2^{*}}$
}

\begin{abstract}
Background: In the United States and Canada, ca. one-half of native orchid species are now threatened with extinction. A number of these species are restricted to tallgrass prairies of central North America, such as the Eastern Prairie Fringed Orchid, Platanthera leucophaea (Nutt.) Lindl._-a U.S. Federally threatened species.

Results: We provide new records of fungi recovered from roots of $P$. leucophaea and five other orchid species inhabiting prairie sites in Illinois and neighboring states during a 10-year period (2008-2017). A total of 39 fungal endophytes were isolated from Cypripedium candidum (1), Platanthera lacera (1), P. leucophaea (32), P. peramoena (3), Spiranthes lacera (1), and S. magnicamporum (1), 31 (79\%) of which were assignable to Ceratobasidium and the remainder to Tulasnella. These fungi were acquired from 16 different sites, 13 of which are new records including two new state records (lowa, Wisconsin). Molecular analysis revealed that some Ceratobasidium strains were virtually identical despite being geographically isolated by $>300 \mathrm{~km}$.

Conclusions: This study, encompassing a decade of work, confirms that Platanthera leucophaea is a mycorrhizal specialist with heavy reliance on Ceratobasidium with the tallgrass prairie ecosystem of North America. Our isolation of Ceratobasidium from P. leucophaea spanning additional sites suggests that the association is widespread. Such information should provide conservationists and land managers with more confidence in developing protocols that facilitate the long-term conservation of this prairie orchid.
\end{abstract}

Keywords: Specificity, Conservation, Endophytes, Mycorrhizal fungi, Tulasnella

\section{Background}

In the United States and Canada, about one-half of native orchid species are now threatened with extinction (Krupnick et al. 2013). A number of these species are restricted to tallgrass prairies of central North America (Bowles 1983) including the Eastern Prairie Fringed Orchid,

\footnotetext{
*Correspondence: Iwzettle@ic.edu

${ }^{2}$ Department of Biology, Illinois College, 1101 W College Ave.,

Jacksonville, IL 62650, USA

Full list of author information is available at the end of the article
}

Platanthera leucophaea (Nutt.) Lindl. (Fig. 1). Millions of hectares of tallgrass prairies have been converted to agriculture resulting in isolated patches of prairie remnants prone to fire suppression, drainage and invasive Old World weeds (Ladd 1995). Today, only ca. $0.1 \%$ of original tallgrass prairie habitat remains (Samson and Knopf 1994; Leach and Givnish 1996), primarily in areas that were never tilled (e.g., cemeteries, railroad tracks), and occasionally in abandoned agricultural fields. These areas currently serve as 'refugia' for rare orchids and their associated biotic agents (e.g., pollinators, mycorrhizal fungi). 


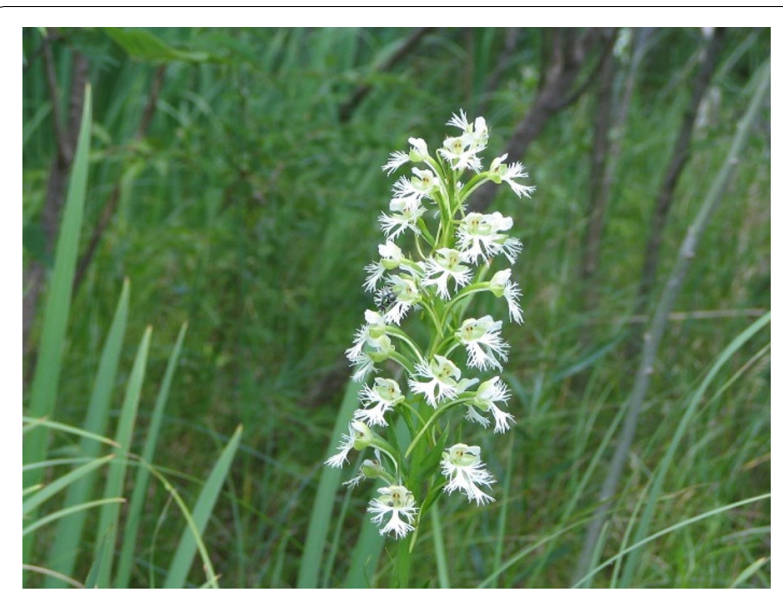

Fig. 1 The U.S. Federally-listed (threatened) Eastern Prairie Fringed Orchid, Platanthera leucophaea (Nutt.) Lindl. (Photo courtesy of Dr. Timothy J. Bell)

Studies researching fungi of orchids inhabiting tallgrass prairies date back to Curtis (1939) who described four 'orchid species of Rhizoctonia' from roots of Habenaria (Platanthera) leucophaea in Wisconsin. More than 60 years later, other studies (e.g., Zettler et al. 2001) documented Rhizoctonia-like fungi from P. leucophaea in several Illinois prairie sites and one in Michigan, supporting Curtis' early work. Most of the fungi recovered were identified as anamorphs in the genus Ceratorhiza using Moore's (1987) classification system which has since been disbanded in favor of the teleomorphic equivalent, Ceratobasidium D.P. Rogers (1935). In addition to roots of mature plants, Ceratobasidium was also recovered with regularity from protocorms and seedlings of $P$. leucophaea (Zettler et al. 2001, 2005; Zettler and Piskin 2011), and several of these strains facilitated in vitro symbiotic seed germination. Thus, P. leucophaea appears to utilize Ceratobasidium fungi spanning the life of the orchid. Ceratobasidium has also been isolated with regularity from other prairie-inhabiting orchids such as P. lacera (Michx.) G. Don (L. Zettler, unpubl. data), Spiranthes vernalis Englemann and Gray (Morton 2015), and P. leucophaea's 'sister species', $P$. praeclara Sheviak and Bowles (Sharma et al. 2003a, b).

Why P. leucophaea associates with Ceratobasidium is not known, but it is conceivable that the orchid targets this fungal genus to best meet its nutritional needs in the unique prairie ecosystem. Understanding the underlying mechanisms that favor the persistence of Ceratobasidium in North American prairies, at least in the few remnant fragments that remain, becomes crucial for orchid conservation in the region. In this paper, we provide new records of fungi recovered from P. leucophaea and five other orchid species inhabiting prairie sites in Illinois and neighboring states, expanding on a comprehensive study by Zettler and Piskin (2011). Fungi were provisionally identified to genus level using standard observational techniques (light microscopy, cultural characteristics). Molecular methods (ITS amplification and sequencing) were also used to confirm identification of select strains, and to detect genetic variation of Ceratobasidium strains within and between orchid populations.

\section{Methods \\ Fungal collection, isolation and identification}

During a 10 year period (2008-2017), living roots from 6 orchid species were collected from tallgrass prairie sites in four states (Illinois, Iowa, Michigan, Wisconsin) during the growing season (June-August). These species consisted of Cypripedium candidum Mühl. ex. Willd., Platanthera lacera (Mich.) G. Don, P. leucophaea (Nutt.) Lindl., P. paramoena (Gray) Gray, Spiranthes magnicamporum Sheviak, and S. vernalis Emgl. and Gray. Lateral roots were detached from donor plants, placed in plastic Ziploc ${ }^{\circledR}$ bags (Dow Chemical Co.) along with soil, and transported to the laboratory within $24 \mathrm{~h}$. Fungi were isolated from roots using the procedures outlined by Zettler and Corey (2018). This process consisted of surface-sterilizing the roots using a sterile solution of $5 \mathrm{ml}$ Clorox ${ }^{\circledR}$ bleach (5.25\% NaOCl, Clorox Co., Oakland, CA), $5 \mathrm{ml}$ absolute ethanol, and $90 \mathrm{ml}$ sterile DI water. Roots were then rinsed twice with sterile DI water, segmented into $1 \mathrm{~mm}$ pieces and placed into separate Petri plates. The segments were macerated thoroughly in a drop of DI water to tease out pelotons from within the root cortex. Molten Fungal Isolation Medium (FIM; Clements et al. 1986) was poured into plates and gently swirled to space the pelotons apart prior to the agar's solidification. Plates were incubated for $24-48 \mathrm{~h}$ at ambient temperature until visible signs of hyphae could be seen growing into the agar. Assisted by a dissection microscope, hyphal tips were removed from fungal colonies using a sterile scalpel and placed onto the surface of Potato Dextrose Agar (PDA, Difco ${ }^{\mathrm{TM}}$, Becton-Dickinson and Co., Sparks, MD). After 1-2 weeks of incubation at ambient temperature, fungal colonies were inspected visually and microscopically. Those that matched published descriptions of fungi in the Rhizoctonia complex (Currah et al. 1997; Zettler and Corey 2018) were retained for further study. Several of these isolates were selected for further identification using molecular (PCR) methods.

\section{Molecular identification}

Molecular identification followed the procedures outlined by Zettler et al. (2013) and Yokoya et al. (2015) involving ribosomal DNA internal transcribed spacer (ITS) amplification and Sanger sequencing. A $1 \mathrm{~cm}^{3}$ 
of fungal inoculum from each culture was added to a flask containing potato dextrose broth (PDB; Sigma Aldrich, St. Louis, MO) and the flask was gently swirled on a shaker for ca. 3 weeks (21-30 days) at ambient temperature until globular fungal colonies measuring ca. $>5 \mathrm{~cm}$ diam. were visible in the broth. The Extract$\mathrm{N}-\mathrm{Amp}^{\mathrm{TM}}$ Plant PCR Kit (Sigma Aldrich) and protocol were used and followed to extract and amplify the fungal DNA from the fungal colonies. DNA primers for amplification and PCR conditions were chosen carefully from White et al. (1990) and Taylor and McCormick (2008) based on what was concluded to work best for the two primary genera of Rhizoctonia-like fungi (Ceratobasidium, Tulasnella). DNA samples that were not used immediately were stored at $-20{ }^{\circ} \mathrm{C}$; however, after multiple amplification attempts, it became clear that the stored DNA samples had decreased in quality and would no longer support PCR amplifications. DNA quality was checked for each sample (gel electrophoresis on a $1.5 \%$ agarose gel at $150-175$ milliamps for 15-20 $\mathrm{min}$ ) and simultaneously quantified using the Nanodrop ${ }^{\circledR}$ (Thermo Scientific) spectrophotometer. Gels stained with ethidium bromide were photographed with a BIO-RAD ChemiDoc ${ }^{\mathrm{TM}}$ MP Imaging System. After extracting DNA from the fungal samples, amplification reaction of $20 \mu \mathrm{l}$ was conducted using primers ITS 1 and 4 or CeTh 1 and CeTh4 (White et al. 1990; Taylor and McCormick 2008) selected based on the findings of White et al. (1990) and purchased from Integrated DNA Technologies (Skokie, IL USA). PCR was using JumpStart Taq Ready Mix from Sigma (St. Louis, MO) and final primer concentrations of $0.4 \mathrm{pmol} / \mu \mathrm{l}$. PCR was carried out in a $\mathrm{LabNet}^{\mathrm{TM}}$ thermocycler with the following conditions: $94^{\circ}$ for $5 \mathrm{~min}$, then 35 cycles of $94^{\circ}$ for $30 \mathrm{~s}$, annealing temperature $48^{\circ}$ (ITS1 and 4 ) or $57^{\circ}$ (CeTh1 and CeTh4) for $30 \mathrm{~s}$, then $72^{\circ}$ for $30 \mathrm{~s}$, followed by a final extension of $72^{\circ}$ for $10 \mathrm{~min}$. After the PCR amplification, the products were visualized through gel electrophoresis as described for the fungal genomic DNA. Successfully amplified DNA was cleaned, and the PCR products were sent to the Core DNA Sequencing Facility at the University of Illinois, Urbana-Champaign. Sample preparation for submission followed their guidelines available at https://unico rn.biotech.illinois.edu/-. An NCBI (National Center for Biotechnology Information) BLAST search was performed on GenBank to identify possible matches to the fungal sequences. Consensus sequences were determined from reactions using the forward and reverse primers and were aligned with their top matches from the BLAST (blastn) search (Altschul et al. 1997; Taylor and McCormick 2008).

\section{Results}

During the 10-year period (2008-2017), a total of 39 new records of fungal endophytes were recovered from six native orchid species from tallgrass prairies in the United States in Illinois, Iowa, Michigan, and Wisconsin, mostly from roots of Platanthera leucophaea in Illinois where the species is most abundant (Table 1, Fig. 2). Of these 39 isolates, 31 (79\%) were assignable to the genus Ceratobasidium, and the remainder to Tulasnella. These fungi were acquired from 16 different sites, 13 of which are new records including two new state records-Iowa (Baldwin Marsh, Jackson Co.) and Wisconsin (Chiwaukee, Kenosha Co.). Of the few (eight) Tulasnella endophytes recovered, six were from P. leucophaea in Bystricky Prairie (McHenry Co., IL) and five of these originated from different juvenile plants spanning 3 years (2012-2014). The other two Tulasnella strains were documented from Sundrop Prairie (Cook Co., IL) and Horn's Prairie (Fayette Co., IL), from roots of mature P. leucophaea and $P$. peramoena, respectively (Table 1 ). Three of the six orchids studied were Platanthera species (P. lacera, P. leucophaea, P. peramoena) and the other three included Cypripedium candidum and two species of Spiranthes (S. magnicamporum, S. vernalis). To our knowledge, this is the first published report documenting fungal endophytes from P. peramoena in North America.

ITS amplification and Sanger sequencing confirmed that all strains collected in 2016 and 2017 were assignable to Ceratobasidium (Table 1). Molecular analysis also revealed that genetically different strains of Ceratobasidium were detected in one specific individual orchid, evidenced by the $P$. leucophaea sample collected in 2016 from the site in Iowa (Baldwin Marsh) that yielded three different strains from a single mature plant (\#158; Table 1). This observation was also noted for a juvenile $P$. leucophaea specimen collected in 2017 in Illinois (Helm Road) that harbored two different Ceratobasidium strains (Table 1). When different strains were genetically analyzed and compared via UPGMA phenogram, virtually identical strains of the same fungus were prevalent in geographically distant regions. For example, Ceratobasidium IC 370 from Michigan (Unionville, Tuscola Co.) displayed nearly identical matches to a strain collected from P. praeclara in NCBI's GenBank repository (Accession number MG662854.11 Benson et al. 2017; Table 1). Moreover, Ceratobasidium IC 365 from a P. leucophaea specimen in Lake Co., Illinois (Lyons Woods) was virtually identical to a strain (IC 426) recovered from $P$. peramoena in Fayette Co. (Horn's Prairie) $>300 \mathrm{~km}$ to the south (Table 1). 
Table 1 A summary of the orchid endophytes recovered from orchids inhabiting tallgrass prairies during the past 10 years (2008-2017)

\begin{tabular}{|c|c|c|c|c|c|c|c|c|}
\hline Year & State & County & Population & Orchid & Growth/Plant ID\# & Fungus & ID\# & Acc. \# \\
\hline 2008 & $\mathrm{IL}$ & Cass & Rexroat Prairie & Sp mag & M & C & IC 350 & - \\
\hline 2011 & $\mathrm{IL}$ & Lake & Wrigley-Abbott & Pleu & M (\#5588) & $C$ & IC 356 & - \\
\hline 2011 & $\mathrm{IL}$ & Lake & Wrigley-Abbott & Pleu & M (\#5509) & $C$ & IC 357 & - \\
\hline 2011 & IL & Lake & Wrigley-Abbott & Pleu & M (\#5568) & C & $\begin{array}{l}\text { IC } 360 \\
\text { UAMH } 11548\end{array}$ & - \\
\hline 2011 & IL & Lake & Wrigley-Abbott & Pleu & M (\#5569) & $C$ & IC 361 & - \\
\hline 2011 & $\| \mathrm{L}$ & Dupage & Swift Prairie & Pleu & M (\#5291) & C & $\begin{array}{l}\text { IC 358/359 } \\
\text { UAMH } 11546\end{array}$ & - \\
\hline 2011 & WI & Kenosha & Chiwaukee & Pleu & M & C & IC 362 & - \\
\hline 2011 & WI & Kenosha & Chiwaukee & Pleu & M & C & $\begin{array}{l}\text { IC } 363 \\
\text { UAMH } 11573\end{array}$ & - \\
\hline 2011 & $\mathrm{IL}$ & Lake & Lyon's Woods & Pleu & M (\#11087) & $C$ & IC 365 & JS546242 \\
\hline 2011 & $\mathrm{IL}$ & Lake & Lyon's Woods & Pleu & M (\#11126) & C & $\begin{array}{l}\text { IC 366/367 } \\
\text { UAMH } 11576\end{array}$ & - \\
\hline 2011 & $\mathrm{IL}$ & Cook & Sundrop Prairie & Pleu & M & $\mathrm{T}$ & IC 368/369 & - \\
\hline 2011 & Ml & Tuscola & Unionville FWS & Pleu & M & C & $\begin{array}{l}\text { IC } 370 \\
\text { UAMH } 11579\end{array}$ & DQ068771 \\
\hline 2012 & $\mathrm{IL}$ & McHenry & Bystricky & Pleu & M (\#7840) & $\mathrm{T}$ & IC 372 & - \\
\hline 2012 & $\mathrm{IL}$ & McHenry & Bystricky & Pleu & M (\#7804) & C & IC 373 & - \\
\hline 2013 & $\mathrm{IL}$ & McHenry & Bystricky & Pleu & J (\#8304) & $\mathrm{T}$ & IC 386 & - \\
\hline 2013 & $\mathrm{IL}$ & McHenry & Bystricky & Pleu & J (\#7890) & C & IC 387 & - \\
\hline 2013 & IL & McHenry & Bystricky & Pleu & $J(\# 7621)$ & C & IC 388 & - \\
\hline 2014 & IL & Fayette & Horn's Prairie & P lacera & M & C & IC 413/414 & - \\
\hline 2014 & $\mathrm{IL}$ & McHenry & Bystricky & Pleu & J (\#7841) & $\mathrm{T}$ & IC 417 & JQ247553 \\
\hline 2014 & $\mathrm{IL}$ & McHenry & Bystricky & Pleu & J (\#7627) & $\mathrm{T}$ & IC 418 & - \\
\hline 2015 & $\mathrm{IL}$ & McHenry & Bystricky & Cyp can & M & $\mathrm{T}$ & IC 419 & - \\
\hline 2015 & $\mathrm{IL}$ & Madison & SIUE-Poag Rd & Sp vern & M & C & $\begin{array}{l}\text { IC } 423 \\
\text { SIUe 9-B }\end{array}$ & - \\
\hline 2015 & $\mathrm{IL}$ & Fayette & Horn's Prairie & P peram & $M(\# 1)$ & C & $\begin{array}{l}\text { IC } 424 \\
\text { SIUe L2CA }\end{array}$ & MG662854 \\
\hline 2015 & $\mathrm{IL}$ & Fayette & Horn's Prairie & P peram & $M(\# 1)$ & $\mathrm{T}$ & $\begin{array}{l}\text { IC } 425 \\
\text { SIUe L2AE }\end{array}$ & AY373273 \\
\hline 2015 & $\mathrm{IL}$ & Fayette & Horn's Prairie & P peram & M & C & $\begin{array}{l}\text { IC } 426 \\
\text { SIUe L1D-0 }\end{array}$ & $J \times 546237$ \\
\hline 2016 & IA & Jackson & Baldwin Marsh & Pleu & M (\#158) & C & SIUe HT100, $(101,103,104)$ & JF912404 \\
\hline 2016 & IA & Jackson & Baldwin Marsh & Pleu & M (\#158) & C & SIUe HT105, M114 & MG662854 \\
\hline 2016 & IA & Jackson & Baldwin Marsh & Pleu & M (\#158) & C & SIUe HT116 & DQ068771 \\
\hline 2016 & $\| \mathrm{L}$ & Cook & Helm Road & Pleu & M (\#5172) & C & SIUe HT102 & AF504008 \\
\hline 2017 & $\mathrm{IL}$ & Will & Grant Creek & Pleu & J (\#3) & C & SIUe HT157 & MG663053 \\
\hline 2017 & IL & Will & Grant Creek & Pleu & J (\#2) & C & $\begin{array}{l}\text { IC } 430 \\
\text { SIUe HT148 }\end{array}$ & - \\
\hline 2017 & $\mathrm{IL}$ & Kane & Lone Grove & Pleu & J (\#2) & C & SIUe HT122 & MG662974 \\
\hline 2017 & $\mathrm{IL}$ & Lee & Nachusa & Pleu & J (\#3) & C & SIUe HT135 & AF504008 \\
\hline 2017 & $\mathrm{IL}$ & Cook & Helmroad & Pleu & J (\#1) & $\mathrm{T}$ & SIUe HT170 & JQ247568 \\
\hline 2017 & $\mathrm{IL}$ & Cook & Helmroad & Pleu & J (\#3) & C & SIUe HT169/198 & AF504008 \\
\hline 2017 & $\| \mathrm{L}$ & Cook & Helmroad & Pleu & J (\#3) & C & SIUe HT196 & MG663023 \\
\hline
\end{tabular}

Fungi denoted by $\mathrm{C}=$ Ceratobasidium, $\mathrm{T}=$ Tulasnella 


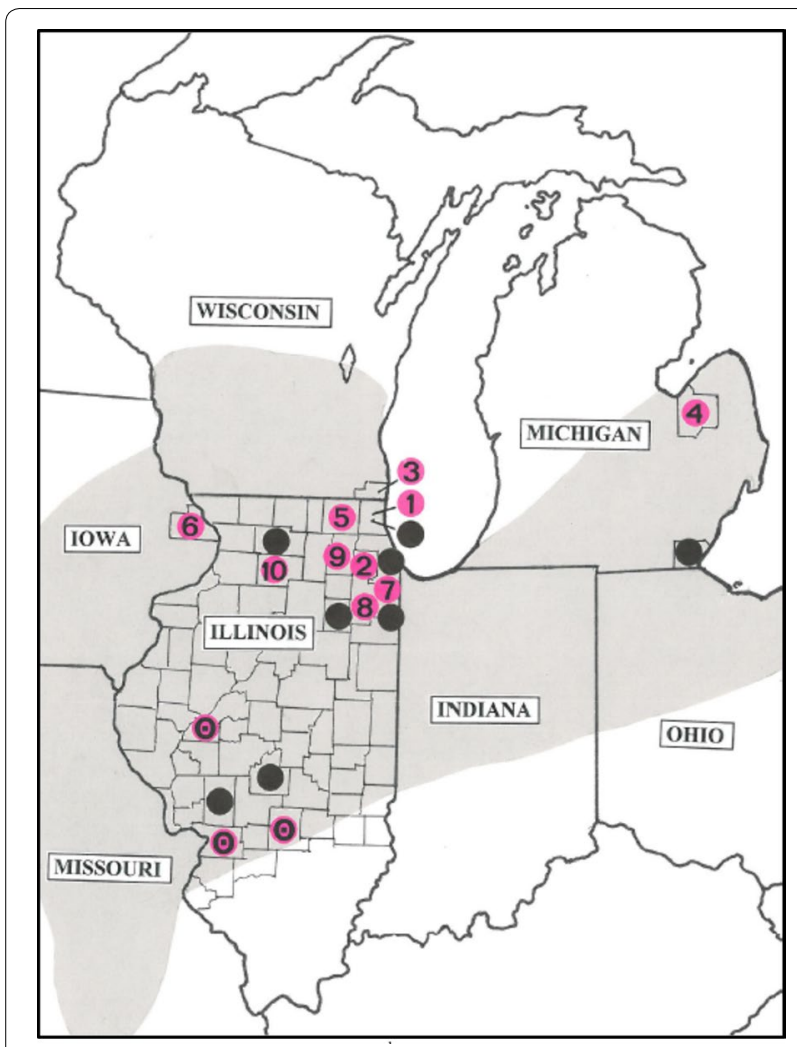

Fig. 2 Locations in the Midwestern United States where Ceratobasidium fungi were isolated from roots and/or protocorms of Platanthera leucophaea as of 2017. The shaded areas reflect the orchid's historic distribution (Bowles 1983). Solid dots indicate locations where Ceratobasidium (=Ceratorhiza) was recovered from P. leucophaea prior to the present study. The two solid dots from lower region of Illinois (Christian and Macoupin Co.) were locations where protocorms of $P$. leucophaea were acquired from seed packets (see Zettler and Piskin 2011). Pink dots with numbers represent sites where Ceratobasidium was acquired from P. leucophaea in the present study: $1=$ Lake Co., IL; $2=$ Dupage Co., IL; $3=$ Kenosha Co., WI; $4=$ Tuscola Co., Ml; $5=$ McHenry Co., IL; $6=$ Jackson Co., IA; $7=$ Cook Co., IL; $8=$ Will Co., IL; $9=$ Kane Co., IL; $10=$ Lee Co., IL. Pink dots lacking a number reflect tallgrass prairie sites where Ceratobasidium was isolated from orchids other than P. leucophaea (i.e., Platanthera lacera, P. peramoena, Spiranthes magnicamporum, S. vernalis)

\section{Discussion}

Compared to other North American orchid species, a modest amount of research has been published with respect to Platanthera leucophaea including its habitat, pollinators, seed germination requirements, and in vitro propagation (e.g., Bowles 1983; Bowles et al. 2002, 2005; Pollack 2009; Stoutamire 1996) in addition to its mycorrhizal associates (e.g., Zettler et al. 2001, 2005). Prior to this study, Zettler and Piskin (2011) documented 75 orchid endophytes in protocorms, seedlings, and roots from mature $P$. leucophaea collected in Illinois and
Michigan, 66 of which (88\%) were identified as Ceratorhiza (=Ceratobasidium), and the remainder were Epulorhiza (=Tulasnella). This study confirmed the presence and persistence of Ceratobasidium in three of the Illinois prairies they reported: Wrigley/Abbott (Lake Co.), Nachusa (Ogle Co.) and Grant Creek (Will Co.). Collectively, 97 of 114 (85\%) of the fungi isolated during a 20-year period by both studies were identified as Ceratobasidium, reaffirming that this genus is the dominant endophyte of $P$. leucophaea in the eastern region of the tallgrass prairie expanse (Fig. 2). Whether or not other co-habiting orchid species utilize Ceratobasidium to a large extent remains to be determined, but the ratio of Ceratobasidium to Tulasnella isolated from all orchid species in the present study was roughly 5 to 1 in favor of the former. In prairies west of the Mississippi River, Ceratobasidium has also been isolated with regularity from roots of the Western Prairie Fringed Orchid, Platanthera praeclara Sheviak and Bowles-the 'sister species' of $P$. leucophaea (Sharma et al. 2003a, b). Interestingly, Morton (2015) determined that a Ceratobasidium endophyte isolated from Spiranthes vernalis in Madison Co., Illinois had a $99 \%$ identity match to one obtained from $P$. praeclara in Clay Co., Minnesota-a distance separated by $>1000 \mathrm{~km}$. Davis et al. (2015) reported that the mycorrhizal fungi utilized by an Australian orchid (Pheladenia deformis) belonged to a single OTU of Sebacina (with one exception) that was present on both sides of the continent (> $2000 \mathrm{~km}$ apart). These studies raise the prospect that $P$. leucophaea and perhaps other orchids of the tallgrass prairie may be mycorrhizal 'specialists' (Swarts and Dixon 2009) that are intimately tied to a narrow group of Ceratobasidium fungi to meet their mycotrophic needs. Indeed, Curtis (1939) predicted that an orchid species restricted to a specific habitat would likely harbor fewer types of fungal associates. The recovery of Ceratobasidium from early growth stages as well as mature plants of P. leucophaea (Zettler et al. 2005; Zettler and Piskin 2011) lends support for this fungal genus serving as the primary mycorrhizal associate (resident) from germination to anthesis. This hypothesis is further strengthened by Thixton (2017) who germinated seeds of P. leucophaea inoculated with three of the Ceratobasidium strains reported herein (IC 370, SIUe HT101-103). New studies are being planned that will test the other 26 fungal isolates (Table 1 ) for their ability to germinate $P$. leucophaea seeds in vitro. Plans are also underway to isolate and safeguard mycorrhizal fungi from additional sites throughout the region (e.g., central Wisconsin) and compare these fungi using molecular techniques. Of particular interest would be to isolate and compare fungi from nutrient-rich Wisconsinan-aged soils to more acidic nutrient poor soils of the Illinoian-aged drift outlined in Bowles et al. (2005). 
Another area of interest would be to study the underlying mechanism(s) behind this close association linked to soil. Tallgrass prairies in the Midwest differ from other orchid habitats in two major respects-they are often regularly burned, and many are surrounded by agricultural land subject to chemical application (e.g., fertilizers). Both practices could conceivably alter soil nutrient levels in ways that affect a range of subterranean lifeforms (e.g., orchid protocorms, mycorrhizal fungi). Leff et al. (2015), in fact, noted that elevated $\mathrm{N}$ and $\mathrm{P}$ input led to a shift in microbial communities in grasslands, including mycorrhizal fungi. Unlike most other plants, orchids generally prefer organic forms of $\mathrm{N}$ to inorganic forms (Rasmussen 1995), and inorganic $\mathrm{N}$ may actually inhibit growth or lead to toxicity (Crawford 1995; Dechorgnat et al. 2011). Additionally, Figura et al. (2019) determined that orchids inhabiting oligotrophic habitats where highly sensitive to nitrate levels compared to orchids inhabiting eutrophic habitats which were largely insensitive. They also linked nitrate levels to orchid distribution because nitrate had a direct role on inhibiting seed germination. Less is known about the role of nutrient sources (mineral or organic) on orchid mycorrhizal fungi, and such information might help resolve whether Ceratobasidium is more prevalent in $P$. leucophaea roots simply because this fungus is more abundant in soil (M. Bowles, pers. com.). Hadley and Ong (1978) reported that isolates of Ceratobasidium cornigerum grew well on nitrate and other nitrogen sources and were more efficient than Tulasnella calospora in their nitrogen 'economy'. More recently, Nurfadilah et al. (2013), explored the impact of potential carbon $(\mathrm{C})$, nitrogen $(\mathrm{N})$ and phosphorous $(\mathrm{P})$ sources on the growth of Ceratobasidium, Sebacina, and Tulasnella-the three primary genera of mycorrhizal fungi in photosynthetic orchids-and demonstrated in vitro that all three fungal genera exploited a 'wide and variable menu' of $\mathrm{C}, \mathrm{N}$ and $\mathrm{P}$ sources. They also determined that these fungi utilized ammonium as the source of inorganic N.

Given that $P$. leucophaea was historically more widespread prior to the conversion of tallgrass prairies to agricultural land, the role of frequent burning might be of particular interest with respect to its impact on the distribution and persistence of mycorrhizal fungi. Ramsay et al. (1986), determined that the abundance and composition of orchid mycorrhizal fungi is influenced by fire in SW Australia, and Bell et al. (2016), concluded that both fecundity and survival of $P$. leucophaea was higher in habitats that were burned. We urge future researchers to also consider examining the role of frequent burning on the prevalence and distribution of orchid mycorrhizal fungi in the tallgrass prairie. Analytically, this might be accomplished by testing various soil types for the prevalence of Ceratobasidium, for example. Experimentally, field tests could be carried out that compare growth and survival of transplanted $P$. leucophaea seedlings in burned versus unburned soils, and by in vitro studies that inoculate test soils with fungi and seeds.

\section{Conclusions}

This study, encompassing a decade of work, confirms that Ceratobasidium serves as the primary mycorrhizal associate of Platanthera leucophaea. Such information serves as a useful baseline for long-term efforts aimed at the orchid's survival in this 'age of extinction'. According to Swarts and Dixon (2009), the ability to conserve terrestrial orchids this century will depend on three actions: (1) management of natural reserves, taking into account the specific needs of the orchids (e.g., mycorrhizal fungi, pollinators), (2) establishing seed and fungal storage 'banks', and (3) developing techniques for orchid restoration. The success of all three actions hinges, at least in part, on knowing more about the fungal associates within the root systems of the orchid and in the landscape. Our isolation of Ceratobasidium from P. leucophaea spanning additional sites suggests that the association is widespread. Such information should provide conservationists and land managers with more confidence in developing protocols that align with the guidelines proposed by Swarts and Dixon (2009).

\section{Acknowledgements}

We express sincere gratitude to Cathy Pollack (U.S. Fish \& Wildlife Service), Marlin L. Bowles and Timothy J. Bell for valuable insight, feedback, and longstanding support of our research efforts throughout the region. We would also like to thank the following people for their assistance with access to orchid material in 2011: Jim Anderson (Lake County Forest Preserves, IL), Debbie Antiltz (Sundrop Prairie, IL), Lori Artiomow (Chiwaukee Prairie, WI), Steve Goldman (The Nature Conservancy), Steve Kahl (USFWS), Debbie Maurer (Lake County Forest Preserves, IL), Nick Miller (The Nature Conservancy), Pat Morton (The Nature Conservancy), Kelly Neal (Illinois DNR). Special thanks to Laurie Ryan (McHenry County Conservation District, IL) for assistance with funding and fieldwork. We also thank the following people for their assistance with data collection: Indianna Som Ogden, Sephra Urbas, and Kayla Tatum (Southern Illinois University-Edwardsville). Data analysis and statistical support from Paul Brunkow and Noah Dell (Southern Illinois University-Edwardsville). The technical support of Andrew L. Stice, Daniel R. Dufau, and Emily Levin (Illinois College) is also appreciated.

An explanation of why your manuscript should be published in Botanical Studies

This manuscript documents the widespread occurrence of fungi assignable to Ceratobasidium associated with U.S. Federally threatened orchid (Platanthera leucophaea) in the tallgrass prairie ecosystem in central North America. The data presented were acquired over a 10 year period and support findings published the decade prior. This study strengthens the hypothesis that $P$. leocophaea is a specialist orchid that relies primarily on mycorrhizal fungi in the genus Ceratobasidium spanning a wide geographical area.

An explanation of any issues relating to journal policies Not applicable. 
Confirmation that all authors have approved the manuscript for submission

All authors have approved the manuscript for submission to Botanical Studies. The photo depicted in Fig. 1 is courtesy of Dr. Timothy Bell.

\section{Confirmation that the content of the manuscript has not been pub-} lished, or submitted for publication elsewhere

The whole or part of the manuscript has not been published or under consideration for publication anywhere else.

\section{Authors' contributions}

HLT, EJE and LWZ conceived the study. LWZ, EJE and HLT conducted field work, fungal isolations and provisional identification. EJE, LLC and HLT performed molecular identification of the fungi. All four co-authors contributed to writing the manuscript. All authors read and approved the final manuscript.

\section{Funding}

Financial support for the acquisition of fungi from P. leucophaea was provided by the U.S. Forest Service (Grant Agreement No. 30181 AG081) to L.W. Zettler. Funding to recover fungi from Bystricky Prairie (IL) was provided by the McHenry County Conservation District. Additional funding was provided the Prairie State Orchid Society, Illinois Orchid Society, Southern Illinois University - Edwardsville Research Grants for Graduate Students (RGGS), and Illinois State Academy of Science Botany Division Travel Grant.

\section{Availability of data and materials}

The authors confirm that local and national guidelines and legislation are followed by acquiring appropriate permissions and licenses for the study.

\section{Ethics approval and consent to participate}

Not applicable.

\section{Competing interests}

The authors declare that they have no competing interests.

\section{Author details}

1 Department of Biology, Southern Illinois University Edwardsville, 1 Hairpin Dr., Edwardsville, IL 62025, USA. ${ }^{2}$ Department of Biology, Illinois College, 1101 W College Ave., Jacksonville, IL 62650, USA. ${ }^{3}$ Present Address: Department of Biology, West Virginia University, P.O Box 6057, Morgantown, WV 26506, USA.

Received: 17 October 2019 Accepted: 4 April 2020

Published online: 15 April 2020

\section{References}

Altschul SF, Madden TL, Schäffer AA, Zhang J, Zhang Z, Miller W, Lipman DJ (1997) Gapped BLAST and PSI-BLAST: a new generation of protein database search programs, No. 17, vol 25. Oxford University Press, Oxford, pp 3389-3402

Bell TJ, Bowles ML, Zettler LW (2016) Factors affecting survival, fecundity and population growth for a North American moth-pollinated prairie orchid (Platanthera leucophaea). In: Gale S (ed) Abstract Booklet—6th international orchid conservation congress, 16-22 May 2016. Hong Kong, Kadoorie Farm and Botanic Garden, 76.

Benson DA, Cavanaugh M, Karsch-Mizrachi I, Lipman DJ, Ostell J, Sayers EW (2017) GenBank. Nucleic Acids Res 45:D37-D42

Bowles ML (1983) The tallgrass prairie orchids Platanthera leucophaea (Nutt) Lindl. and Cypripedium candidum Muhl. Ex Willd.: some aspects of their status, biology and ecology, and implications toward management. Nat Areas J 3(4):14-37

Bowles ML, Jacobs KA, Zettler LW, Wilson Delaney T (2002) Crossing effects on seed viability and experimental germination of the Federal threatened Platanthera leucophaea (Orchidaceae). Rhodora 104:14-30

Bowles ML, Zettler LW, Bell TJ, Kelsey P (2005) Relationships between soil characteristics, distribution, and restoration potential of the Federal threatened Eastern Prairie Fringed Orchid, Platanthera leucophaea (Nutt) Lindl. Am Mid Nat 154:273-285

Clements MA, Muir H, Cribb PJ (1986) A preliminary report on the symbiotic germination of European terrestrial orchids. Kew Bull 41:437-445
Crawford NM (1995) Nitrate: nutrient and signal for plant growth. Plant Cell 7:859-868

Currah RS, Zelmer CD, Hambleton S, Richardson KA (1997) Chapter 4. Fungi from orchid mycorrhizas (pp 117-170). In: Arditti J, Pridgeon AM (eds) Orchid biology: reviews and perspectives, VII. Springer, Netherlands

Curtis JT (1939) The relation of specificity of orchid mycorrhizal fungi to the problem of symbiosis. Am J Bot 26:390-399

Davis BJ, Phillips RD, Wright M, Linde CC, Dixon KW (2015) Continent-wide distribution of mycorrhizal fungi: implications for the biogeography of specialized orchids. Ann Bot 116:413-421

Dechorgnat J, Nguyen CT, Armengaud P, Jossier M, Diatloff E, Filleur S, DanielVedele $F(2011)$ From the soil to the seeds: the long journey of nitrate in plants. J Exp Bot 62:1349-1359

Figura T, Weiser M, Ponert J (2019) Orchid seed sensitivity to nitrate reflects habitat preferences and soil nitrate content. Plant Biol 22(1):21-29

Hadley G, Ong SH (1978) Nutritional requirements of orchid endophytes. New Phytol 81:561-569

Krupnick G, McCormick MK, Mirenda T, Whigham DF (2013) The status and future of orchid conservation in North America. Ann Mo Bot Gard 99(2):180-198

Ladd DM (1995) Tallgrass prairie wildflowers. Falcon Publishing, Inc. (The Globe Pequot Press), Guilford

Leach MK, Givnish TJ (1996) Ecological determinants of species loss in remnant prairie. Science 273(5281):1555-1558

Leff JW, Jones SE, Prober SM, Barberán A, Borer ET, Firn JL, Harpole SW, Hobbie SE, Hofmockel KS, Knops JMH, McCulley RL, La Pierre K, Risch AC, Seabloom EW, Schültz M, Steenbock C, Stevens CJ, Fierer N (2015) Consistent responses of soil microbial communities to elevated nutrient inputs in grasslands across the globe. Proc Nat Acad Sci USA 112(35):10967-10972

Moore RT (1987) The genera of Rhizoctonia-like fungi: Ascorhizoctonia, Ceratorhiza gen. nov., Epulorhiza gen. nov., Moniliopsis, and Rhizoctonia. Mycotaxon 29:91-99

Morton WG (2015) Isolating mycorrhizal fungi from Spiranthes vernalis for subsequent in vitro seed germination (Order No. 10010820). Master's Thesis. Southern Illinois University Edwardsville

Nurfadilah S, Swarts ND, Dixon KW, Lambers H, Merritt DJ (2013) Variation in nutrient-acquisition patterns by mycorrhizal fungi of rare and common orchids explains diversification in a global biodiversity hotspot. Ann Bot 111(6):1-9

Pollack C (2009) Restoration of the Eastern Prairie Fringed Orchid (Platanthera leucophaea): natural pollinators and abundance of larval host plant. Master's Thesis. Northeastern Illinois University

Ramsay RR, Dixon KW, Sivasithamparam K (1986) Patterns of infection and endophytes associated with Western Australian orchids. Lindl 1(3):203-214

Rasmussen HN (1995) Terrestrial orchids from seed to mycotrophic plant. Cambridge University Press, Cambridge

Rogers DP (1935) Notes on the lower Basidiomycetes. Univ lowa Stud Nat Hist 17:3-43

Samson F, Knopf F (1994) Prairie conservation in North America. BioScience 44(6):418-421

Sharma J, Zettler LW, Starbuck CJ (2003a) A survey of mycobionts of federallythreatened Platanthera praeclara (Orchidaceae). Symbiosis 34:145-155

Sharma J, Zettler LW, Van Sambeek JW, Ellerseck M, Starbuck CJ (2003b) Symbiotic seed germination and mycorrhizae of federally-threatened Platanthera praeclara (Orchidaceae). Am Mid Nat 149:79-95

Stoutamire WP (1996) Seeds and seedlings of Platanthera leucophaea (Orchidaceae), p. 55-61. In: Allen C (ed) Proceedings of the North American native terrestrial orchid-propagation and production conference. National Arboretum, Washington, D.C

Swarts ND, Dixon KW (2009) Terrestrial orchid conservation in the age of extinction. Ann Bot 104:543-556

Taylor DL, McCormick MK (2008) Internal transcribed spacer primers and sequences for improved characterization of basidiomycetous orchid mycorrhizas. New Phytol 177:1020-1033

Thixton HL (2017) Identification of site-specific mycorrhizal fungi associates of the Federally threatened Eastern Prairie Fringed Orchid (Platanthera leucophaea) in Illinois. MS Thesis. Southern Illinois University at Edwardsville, $78 \mathrm{p}$ 
White TJ, Bruns T, Lee S, Taylor DL (1990) Amplification and direct sequencing of fungal ribosomal RNA genes for phylogenetics. PCR Protocols: A guide to methods and applications, pp 315-322

Yokoya K, Zettler LW, Kendon JP, Bidartondo MI, Stice AL, Skarha S, Corey LL, Knight AC, Sarasan V (2015) Preliminary findings on identification of mycorrhizal fungi from diverse orchids in the Central Highlands of Madagas car. Mycorrhiza 25:611-625. https://doi.org/10.1007/s00572-015-0635-6

Zettler LW, Corey LL (2018) Orchid mycorrhizal fungi: isolation and identification techniques. In: Lee Y-I, Yeung EC-T (eds) Orchid propagation from laboratories to greenhouses_methods and protocols. Springer Nature, Berlin. https://doi.org/10.1007/978-1-4939-7771-0_2

Zettler LW, Piskin KA (2011) Mycorrhizal fungi from protocorms, seedlings and mature plants of the Eastern Prairie Fringed Orchid, Platanthera leucophaea (Nutt.) Lindley: a comprehensive list to augment conservation. Am Mid Nat 166:29-39

Zettler LW, Stewart SL, Bowles ML, Jacobs KA (2001) Mycorrhizal fungi and cold assisted symbiotic germination of the Federally threatened Eastern
Prairie Fringed Orchid, Platanthera leucophaea (Nutt.) Lindl. Am Mid Nat 145:168-175

Zettler LW, Piskin KA, Stewart SL, Hartsock JJ, Bowles ML, Bell TJ (2005) Protocorm mycobionts of the Federally threatened Eastern Prairie Fringed Orchid, Platanthera leucophaea (Nutt.) Lindl., and a technique to prompt leaf elongation in seedlings. Stud Mycol 53:163-171

Zettler LW, Corey LL, Jacks AL, Gruender LT, Lopez AM (2013) Tulasnella irregularis (Basidiomycota: Tulasnellaceae) from roots of Encyclia tampensis in south Florida, and confirmation of its significance through symbiotic seed germination. Lankesteriana 13(1-2):119-128

\section{Publisher's Note}

Springer Nature remains neutral with regard to jurisdictional claims in published maps and institutional affiliations.

\section{Submit your manuscript to a SpringerOpen ${ }^{\circ}$ journal and benefit from:}

- Convenient online submission

- Rigorous peer review

- Open access: articles freely available online

- High visibility within the field

- Retaining the copyright to your article

Submit your next manuscript at $\boldsymbol{\nabla}$ springeropen.com 